Original Article

\title{
HYPOPHARYNGEAL GLAND ACTIVITY IN TASK-SPECIFIC WORKERS UNDER BROOD AND BROODLESS CONDITIONS
}

\section{IN APIS CERANA INDICA (Fab.)}

\author{
Seydur Rahman \\ Ibamelaker Thangkhiew \\ Sudhanya R. Hajong* \\ Department of Zoology, North-Eastern Hill University \\ 793022 Shillong, India \\ *corresponging author: srhajong@nehu.ac.in \\ Received 20 May 2014; accepted 12 November 2014
}

\begin{abstract}
The hypopharyngeal gland (HPG) is the principal organ of protein synthesis in honey bees. It is involved in larval rearing. We examined the fresh head weight, HPG acini diameter, and HPG protein content in worker bees engaged in different tasks and under brood and broodless conditions. Scanning electron microscopy revealed that the HPG acini diameter of worker bees was related to their task. The highest HPG volume was found in nurse bees, and the volume regressed when the task changed from guarding to foraging. The fresh head weight was positively correlated with HPG acini diameter. Although, there was no positive correlation between HPG acini diameter and protein concentration, the glandular protein concentration increased progressively in nurse bees and declined in guard and forager bees. Histochemistry revealed similar results. Despite displaying significantly larger glands, guard bee protein secretion was similar to that of the foragers. Brooding had a significant effect on HPG activity. Only worker bees from the colony with an intact brood showed elevated rates of protein synthesis; thus, it is possible that a signal was emitted by the brood, which stimulated protein synthesis in the HPG. However, the size of the HPG was similar in both brood and broodless conditions.
\end{abstract}

Keywords: Apis cerana indica, brood, broodless, hypopharyngeal gland, hypopharyngeal gland activity.

\section{INTRODUCTION}

The various tasks performed for colony maintenance in a bee hive are carried out by worker bees. As they progress in age, worker bees shift their tasks. Normally, early workers perform hive activities like cleaning, nursing, and guarding; then, they perform the external task of foraging. The worker bees engaged these age-based tasks normally cannot be distinguished by external morphology. However, internally, the major differences between these workers are the activity of various glands, their secretory activities, gland morphology, and gland physiology. One such gland is the hypopharyngeal gland (HPG), which was first described in 1846 by Nickel (Ribbands, 1953). The hypopharyngeal gland is the principal gland that secretes a proteinaceous substance known as "Royal Jelly"; hence, the HPG is also referred to as the "Royal Jelly gland". The HPG is composed of secretory units that comprise several secretory cells. The protein secreted by these cells is collected in the intracellular canaliculus (Cruz Landim and Hadek, 1969), and then it is released through the extracellular excretory canaliculus into the axial duct or the hypopharyngeal plate.

Based on the opening of the excretory canaliculi, HPGs have been categorized into four different types. Type- 1 glands have secretory units that are directly connected to the hypopharyngeal plate through their individual excretory canaliculi; Type-2 glands have individual excretory canaliculi attached to the outer covering of hypopharyngeal plate. Type-3 glands have a central axial duct that delivers the secretion received from the acini into the oral cavity through a long, single opening in the hypopharyngeal plate. Glands with an axial duct more extended than that in Type-3 glands are grouped as Type-4 glands.

HPG may also show differences based on the degree of sociability of a species. In some groups 
of Hymenoptera, the HPG is composed of unicellular acini, and others have pluricellular acini. Solitary bees tend to have Type-1 HPG morphology (CruzLandim, 1967). However, in the highly social wasp, Polistes, the three castes have different HPG types. The queen and the males have Type-1 HPGs, and the workers have Type-2 HPGs. The presence of these different types within the same species suggests a difference in HPG function (Cruz-Landim and Saenz, 1972). Previous studies showed that the diameters of HPGs could be used to describe the physiological condition of the worker honey bee (Hrassnigg and Crailsheim, 1998).

The HPG has been well studied in Apis mellifera (Cruz-Landim, 1967; Crailsheim and Stolberg, 1989; Knecht and Kaatz, 1990) and in some Meliponinea (Cruz-Landim, 1967; Cruz-Landim et al., 1987). In A. mellifera, the queens and males do not possess the HPG, but the workers have HPGs with pluricelIular acini. Furthermore, the HPG shows a well defined secretory cycle in the workers, which is closely linked to their tasks (Deseyn and Billen, 2005; Suwannapong et al., 2010). Newly emerged worker bees do not possess a well developed gland, but in the brood-caring phase of the workers, the HPG is fully developed. During the foraging phase, the gland enters a postsecretory stage, and it undergoes involution or shrinkage (Kratky, 1931; Snodgrass, 1956; Cruz-Landim and Hadek, 1969). This shrunken HPG in foraging or older workers may be reverted back to a fully functional HPG, depending on the requirement of the colony; this capability suggested that HPG activity is correlated with the tasks performed (Silva et al., 1985; Bloom, 1993; Cruz-Landim et al., 2000). Similarly, secretory cycles related to the division of labor were also reported in a few Meliponinea species (Cruz-Landim et al., 1987; Costa and Cruz-Landim, 2000). For example, in the Meliponinea species Scaptotrigona postica, one study revealed the presence of HPGs in both the males and females (Costa and CruzLandim, 1977). The glands were more developed in the queens and the males among newly emerged bees. In the broodcare workers, the HPG displayed maximum development (Costa and Cruz-Landim, 1999). In the Bombus species and in ants, the HPGs are proportionally largest in the queens, followed by the workers and males (Lauer, 1975; Gama and Cruz-Landim, 1982).

In honey bee colonies, the interaction between adult workers and brood is a universal phenomenon and an integral part of social organization (Michener, 1974). The HPG plays a primary role in adult-brood interactions. The nutrients from pollen collected by the workers are made available to the brood and the queen by conversion to proteinaceous Royal Jelly within the HPG. Glandular secretions of Royal jelly are discharged into the buccal cavity of the workers, so that it can be added to food in the mouth. Workers that specialize in nursing transfer this jelly mixture to nestmates through the process of trophallaxis (Crailsheim, 1991). It has been postulated that HPG production of Royal jelly depends on the presence of a brood in the colony. Thus, the presence of a brood might act as a signal to stimulate the HPG to initiate protein synthesis (Brouwers, 1982, 1983; Huang et al., 1989). Mohammedi et al. (1996) found that this signal involved a chemical messenger known as a "Brood pheromone".

During nursing or brood-caring, the worker bees produce copious proteins in the HPG. Conversely, when workers perform extranidal activities, such as foraging, the HPG produces less protein. During the latter stage, the HPG also produces carbohydrate and honey-processing enzymes, like glucosidase oxidase (Ohashi et al., 1999) and $\alpha$-glucosidase (Kratky, 1931), and other enzymes, including galactosidase, esterase, lipase, leucine arylamidase, and even invertase (Costa, 2002).

The function of the HPG has been well established in $A$. mellifera. In that species, the nurse workers produce the highest concentrations of protein in the Royal Jelly (Patel et al., 1960; Klaudiny et al., 1994; Kubo et al., 1996). This was substantiated in histochemical studies of HPG performed in different behavioral stages of $A$. mellifera and $A$. cerana. Those studies showed that, in nurse bees, the HPG harbors the highest protein concentration among all the task groups; then later, the concentration decreases in older workers. Furthermore, the acini were largest in the nurse bees and smallest in the guard bees (Deseyn and Billen, 2005; Suwannapong et al., 2010). As the workers advanced in age, the number of secretory vesicles in the HPG also correspondingly decreased, and then, nearly disappeared during the foraging period (Deseyn and Billen, 2005). The primary objective of the present study was to understand the pattern of HPG activity associated with age-related shifts in the tasks of worker bees of Apis cerana indica (Fab.). We also investigated the effect of an absence of brood on the HPG activity of the worker bees in a colony. We followed the activity cycle in the worker bees of advanced ages by examining the HPG with scanning electron microscopy. We used Ninhydrin Schiff (NHS) and Periodic Acid-Schiff (PAS) staining to localize and detect the changes in concentration of proteins and carbohydrates in the HPGs of workers of different ages and in different task groups. We estimated the changes in protein concentrations that occurred in 
the HPGs of different workers with the Bradford assay. We measured the diameters of HPG acini in workers performing age-specific tasks to determine whether the HPG changes its activity with different age-specific tasks.

\section{MATERIAL AND METHODS}

\section{Experimental design}

We maintained two experimental colonies. The first consisted of a normal $A$. $c$. indica colony that contained broods (brood colony); the queen was allowed free movement and freedom to lay eggs normally. In the second colony, all the broods were removed (broodless colony); the queen was held in a cage placed in-between the combs at the center of the colony. Both colonies had sufficient amounts of pollen and honey throughout the experiment.

\section{Coding and introduction of bees}

Three combs from the brood colony, which contained pupae ready to emerge, were placed in an incubator and maintained at $34.5^{\circ} \mathrm{C}, 60 \%$ relative humidity. After $12 \mathrm{~h}$, newly emerged bees ( $n=180$ on the $1^{\text {st }}$ day and $n=223$ on the $2^{\text {nd }}$ day) were marked individually according to the day of emergence with Fabrica Acrylic Colour (Camlin Kokuyo, Mumbai, India) on the thorax and abdomen. The bees were then placed on combs of both the brood and broodless colonies.

\section{Determination of fresh head weight, HPG acini diameter, and protein concentration}

The marked worker bees were collected from the colonies after 1, 4, 8, 12, 16, and 21 days. Collected bees were killed by chilling on ice. Bee age was defined as the time starting from their introduction to the experimental colony after tagging. Additionally, bees from four task groups (1: newly emerged, 2: nurse, 3: guard, and 4: foragers) were also collected to measure the task-specific changes in the parameters mentioned below. Newlyemerged workers were collected immediately after emergence and were less than $1 \mathrm{~h}$ old. Nurse bees were collected when the bees were feeding the broods. Guard bees were collected by introducing anesthetized alien bees at the entrance of the hive (guard bees immediately emerge from the hive and show aggressive behavior). Foragers were non-coded and of unknown age. They were collected at the hive entrances, as they returned from a flight with pollen on their corbicula. All sampling was performed with minimal disturbance.

\section{Measurement of fresh head weight}

All bees used for the examination of HPGs were decapitated, and the fresh weights of the heads were measured. Weights were determined immediately after collecting the bees from hives and before dissecting the glands.

\section{HPG acini diameter measurement}

Ten workers of each age group and task group were dissected under a streozoom microscope (Magnus, New Delhi), and the HPG was removed and placed in Ringer solution $\left(\mathrm{NaCl}, \mathrm{KCl}, \mathrm{CaCl}_{2}, \mathrm{NaHCO}_{3}\right)$. Each gland was mounted in a drop of Ringer solution on a glass slide. Ten acini were randomly selected from each HPG, and diameters were measured perpendicular to the long axis of the oval acinus with an ocular micrometer on a binocular microscope (Motic B1 220, Hong Kong).

\section{Analysis of HPG protein}

Protein levels were estimated by pooling HPGs from ten worker bees per group. HPGs were homogenized in $1.5 \mathrm{~mL}$ microcentrifuge tubes that contained $0.1 \mathrm{M}$ phosphate buffer solution ( $\mathrm{pH} 7.4)$ on ice. Subsequently, homogenates were centrifuged at $1500 \mathrm{rpm}$ for $10 \mathrm{~min}$ at $4^{\circ} \mathrm{C}$, and the protein content in the supernatant was estimated with the Bradford assay (1976); bovine serum albumin was used as a standard. Protein absorbance was measured at $595 \mathrm{~nm}$ with a Cary 50 UV-visible spectrophotometer.

\section{Tissue processing for histochemistry with Ninhydrin Schiff and Periodic Acid-Schiff}

For light microscopy, the worker bees of all the task groups were dissected in Ringer's solution under a binocular microscope to remove the HPG. The HPG was then fixed in Bouin's fluid, washed in $70 \%$ alcohol, and dehydrated in a series of alcohol grades. The tissue was cleared in xylene and then bathed in a series of different xylene and paraffin mixtures (ratios, 3:1, 1:1, and $1: 3$ ) at $58-60^{\circ} \mathrm{C}$. The tissues were finally embedded in pure paraffin. Blocks were sliced in 6- $\mu \mathrm{m}$ sections. Slides were deparaffinized with xylene, followed by dehydration in a series of alcohol grades, as described by Humason (1962). After this, the slides were stained with NHS and PAS for localization of proteins and carbohydrates. Microphotography was performed with a Leica Microscope fitted with a camera. 


\section{Sample processing for scanning electron microscopy}

For scanning electron microscopy (SEM), HPGs were fixed in $2.5 \%$ glutaraldehyde in $0.1 \mathrm{M}$ sodium phosphate buffer ( $\mathrm{pH} 7.4)$ for $6 \mathrm{~h}$, then washed in $0.1 \mathrm{M}$ sodium cacodylate buffer. Dehydration was performed with a series of acetone washes (from $30 \%$ to $100 \%$ acetone) for 15 min each, with two wash exchanges. Next, the HPGs were immersed in tetramethylsilane (Dey,1993) for $10 \mathrm{~min}$, with two wash exchanges. All steps were carried out at $4^{\circ} \mathrm{C}$. The HPGs were then brought to room temperature $\left(25-26^{\circ} \mathrm{C}\right)$, allowed to dry, then mounted onto brass stubs. The glands were then gold-coated (35 nm thick) and viewed with a JSM-6360 SEM (JEOL, USA).

\section{Statistical analysis}

One-way ANOVA was used to determine significant differences in acini diameters or protein concentrations between the worker task groups. Two-way ANOVA was also applied to determine differences between bee colonies i.e., brood and broodless colonies in relationships between acini diameters or protein concentrations and age. Data from each task group and age group were also subjected to a Tukey HSD post-hoc analysis to examine possible individual significant differences in acini diameters and protein concentrations. Regression analyses were performed to detect significant correlations between fresh head weights and acini diameters and also between acini diameters and protein concentrations. Statistical tests were conducted with Origin Pro 8. A p-value $<0.05$ was considered significant.

\section{RESULTS}

\section{Acini diameters related to specific tasks}

Acini diameters in adult worker bees were found to depend on the type of tasks performed (one-way ANOVA: $F_{3,199}=297.89$, $p<0.05$; Fig. 1). Nurse bees had significantly higher $(210.80 \pm 3.63 \mu \mathrm{m})$ acini diameters than the newly emerged bees (104.40 \pm $2.28 \mu \mathrm{m})$, guard bees $(125 \pm 1.984 \mu \mathrm{m})$, and forager bees $(107.8 \pm 3.34 \mu \mathrm{m})$. Also, the acini diameters were not significantly different between newly emerged and forager bees.

\section{Acini diameter related to age}

We found no significant difference in acini diameters between bee colonies (two-way ANOVA: $F_{1,767}=0.06 ; p>0.05$; Fig. 2), however, both colonies showed significant changes in acini diameters at different ages (days) (two-way ANOVA: $\left.F_{6,767}=222.08 ; p<0.0001\right)$. Further, the interaction between bee colonies and ages were also found to be significantly different (two-way ANOVA: $\left.F_{6,767}=38.78 ; p<0.0001\right)$. The colonies showed similar patterns of change in acini diameters with respect to age. The acini diameters significantly increased on day $4(p<0.05)$ and peaked on day 8; moreover, the groups showed similar peak acini diameters (brood $=207 \pm 7.77 \mu \mathrm{m}$; broodless $=212.6 \pm 11.14 \mu \mathrm{m})$. Gland regression was evident on day 12 , when acinar diameters decreased in both groups (brood $=166.20 \pm 5.57 \mu \mathrm{m}$; broodless $=175.20 \pm 9.04 \mu \mathrm{m})$; this was followed by a slight increase on day 16 (brood $=182.20 \pm 7.30 \mu \mathrm{m}$;

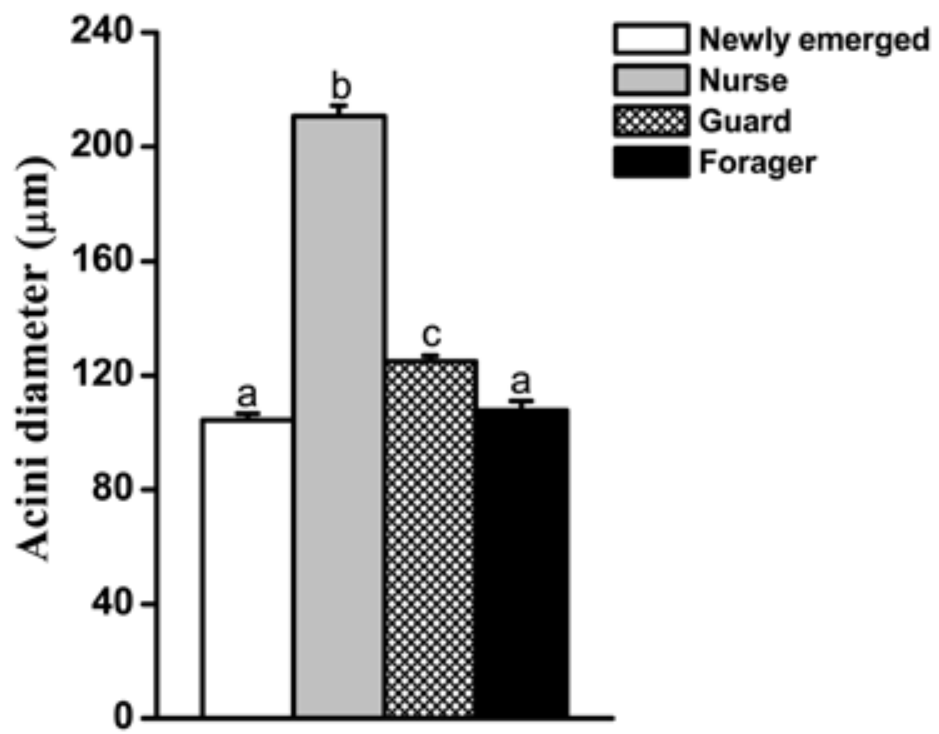

Fig. 1. Hypopharyngeal gland acini diameters $(\mu \mathrm{m} \pm \mathrm{SD}$ ) of worker bees from different task groups. Nurse bees showed significantly higher acini diameters than the other task groups. Means labeled with the same letter do not differ significantly according to Tukey HSD procedure. 


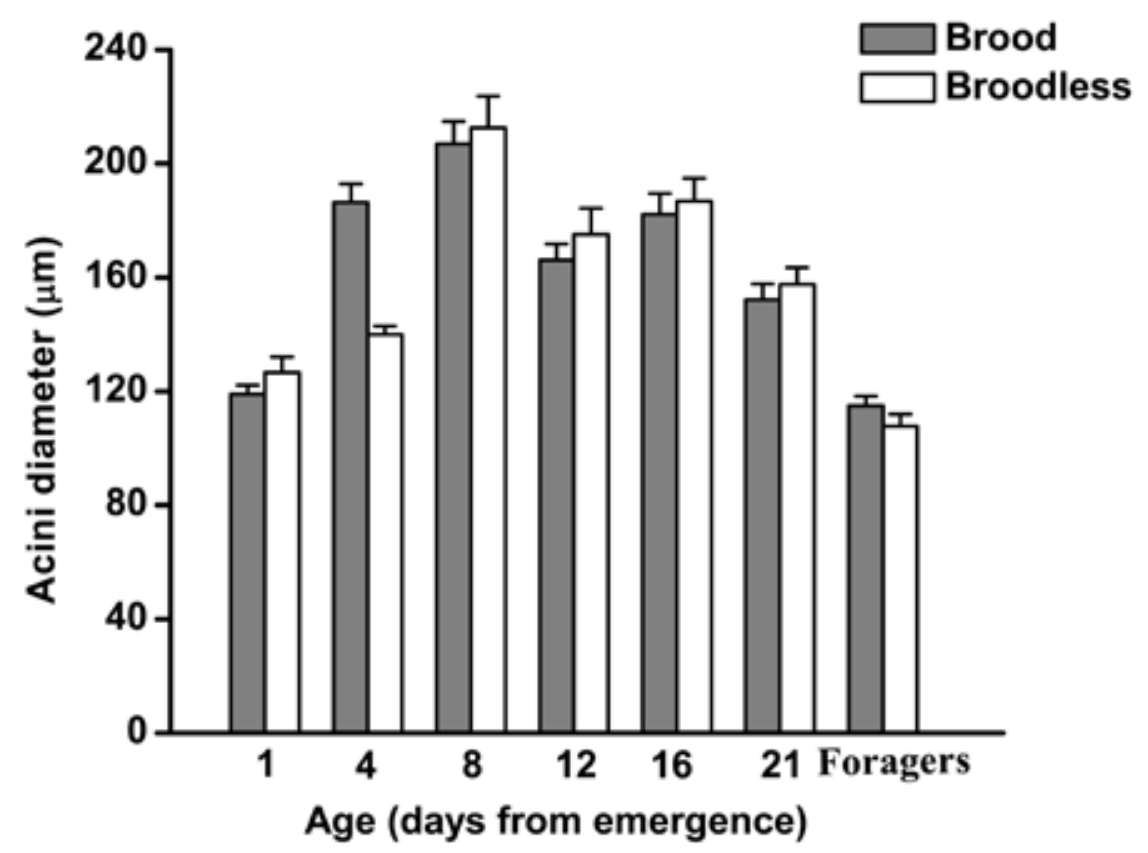

Fig. 2. Development of hypopharyngeal gland acini sizes $(\mu \mathrm{m} \pm \mathrm{SD})$ in worker bees of different ages (days) placed in brood or broodless colonies. Foragers are $>21$ days from emergence.

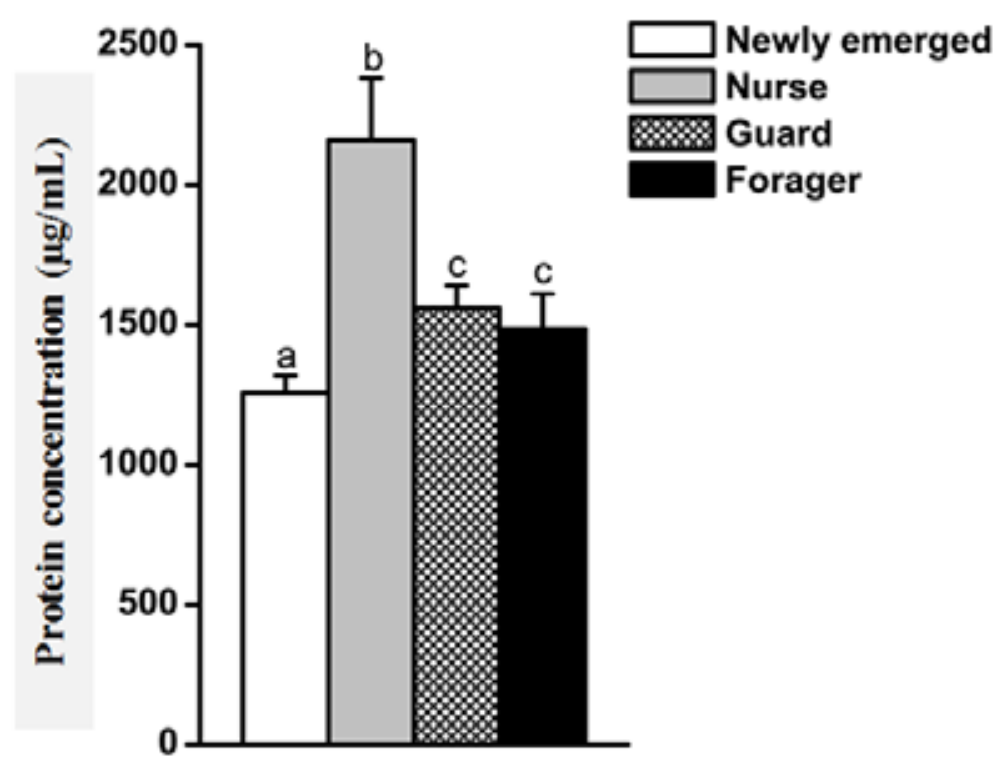

Fig. 3. Hypopharyngeal gland protein concentrations $(\mu g / \mathrm{mL} \pm$ SD) in newly emerged, nurse, guard, and forager bees. Means labeled with the same letter do not differ significantly according to Tukey HSD procedure.

broodless $=186.8 \pm 8.04 \mu \mathrm{m})$. Finally, on day 21 , the acini diameters significantly declined $(p<0.05)$, and they continued to decline in forager bees.

\section{HPG protein production related to tasks}

The different task groups varied significantly in HPG protein content (one-way ANOVA: $F_{3,19}=$ 12.91, $p<0.0001$; Fig. 3). Newly emerged bees had
HPGs with the least amount of protein (1256.39 \pm $62.15 \mu \mathrm{g} / \mathrm{mL}$ ). A post-hoc analysis revealed that the HPG protein content of nurse bees was significantly higher $(p<0.001)$ than the contents found in other task groups. However, guard and forager bees displayed nearly the same amounts of HPG protein $(p=0.97)$. 


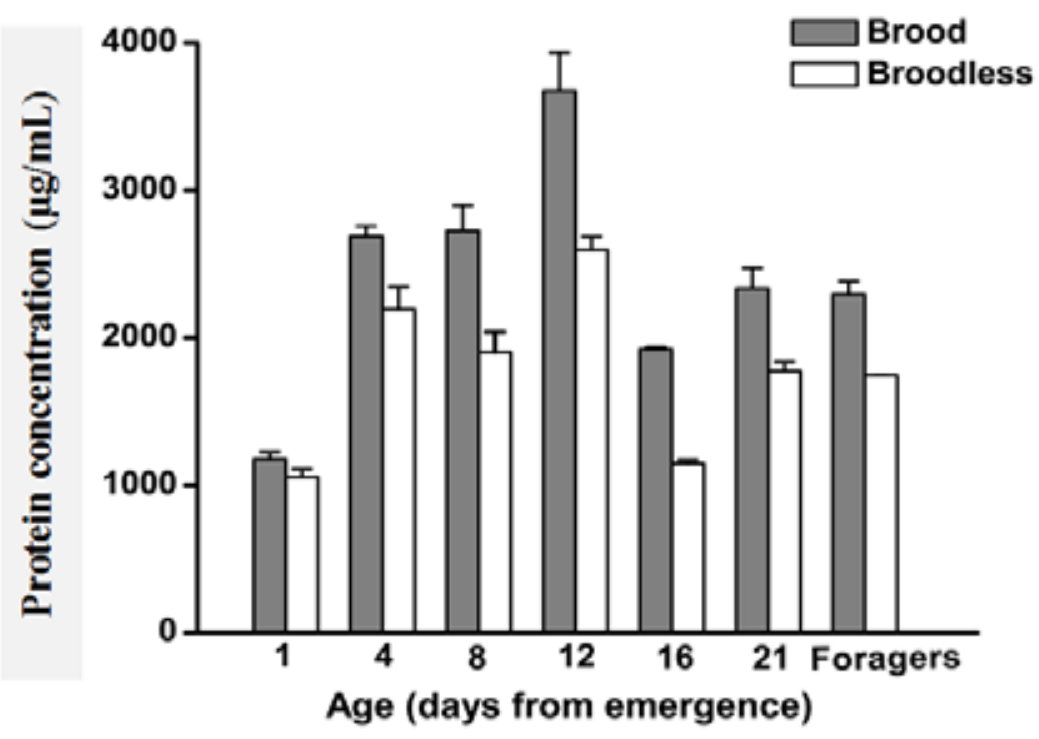

Fig. 4. Protein concentrations in the hypopharyngeal glands of worker bees of different ages (days after emergence) that were placed in brood or broodless colonies. Means ( \pm SD) were calculated from 10 worker bees in each group.

HPG protein production related to age in workers in brood and broodless colonies

Worker bees showed significant differences in HPG protein levels at different ages under both brood and broodless conditions (two-way ANOVA; ages: $F_{6.55}=61.38 ; p<0.0001$; bee colonies: $F_{1.55}=100.26$; $p<0.0001$; interaction between bee colonies and ages: $F_{6.55}=3.33 ; p<0.001$; Fig. 4). In workers from the brood colony, HPG protein levels were significantly higher $(p<0.05)$ during the nursing phase than during other phases. The first significant $(p<0.05)$ increase in protein level was observed on day 4; it reached a peak on day 12 in workers of both the brood $(3671.90 \pm 262.94 \mu \mathrm{g} / \mathrm{mL})$ and broodless (2595.59 $\pm 90 \mu \mathrm{g} / \mathrm{mL}$ ) colonies. A significant decline $(P<0.05)$ in HPG protein was observed on day 16; but then, levels were maintained through the foraging phase in both colonies.

\section{HPG development related to fresh head weight and protein concentration}

We found a significant positive correlation between fresh head weights and HPG acini diameters in bees performing different tasks $\left(r^{2}=0.81, p<0.0001\right.$; Fig. 5a). A similar pattern was observed when the head weights of workers from brood and broodless colonies were compared to HPG development (Brood colony: $r^{2}=0.70, p<0.0001$; Broodless colony: $r^{2}=0.72, p<0.0001$; fig. $5 b$ and $5 c$, respectively). Thus, the weights of fresh heads can serve as an indicator of the developmental stage of the HPGs.
Bees with heavier heads, such as nurses $\left(4^{\text {th }}, 8^{\text {th }}\right.$, and $16^{\text {th }}$ days), had voluminous glands, but, foragers had lighter heads and regressed acini.

HPG size did not necessarily correlate with the level of protein secreted. Bees performing different tasks and bees from brood colony showed no correlation between acini size and protein concentration; however, size and concentration were significantly related (Task: $r^{2}=0.58, p<0.0001$; Brood colony: $r^{2}=0.25, p<0.003$; Fig. $5 d$ and $\left.5 e\right)$. Similarly, no significant correlation was observed between HPG size and its protein concentration in the broodless colony $\left(r^{2}=0.01, p=0.25 ;\right.$ Fig. 5f $)$.

\section{Morphology of HPG}

SEM and light microscopic observations revealed that the HPG took the shape of long clusters surrounding an elongated central axial duct. The average length of the central axial duct was $1.15 \pm$ $0.08 \mathrm{~cm}$ in worker bees. The glands were paired structures composed of numerous secretory units, or acinus (ac), that were connected to the central axial duct by a thin, individual, excretory canaliculi (cc) (Fig. 6a). The glands discharged the secretion received from the secretory units into the oral cavity through a large common opening in the hypopharyngeal plate (not shown). Glands with these features are characterized as Type-4 glands. In newly emerged workers, the glands were not fully developed (Fig. 6b); they were irregular in shape. In the nurse bees, the glands achieved maximum 


\section{J. APCL. SCLI. VOL. 58 NOL. 22014}
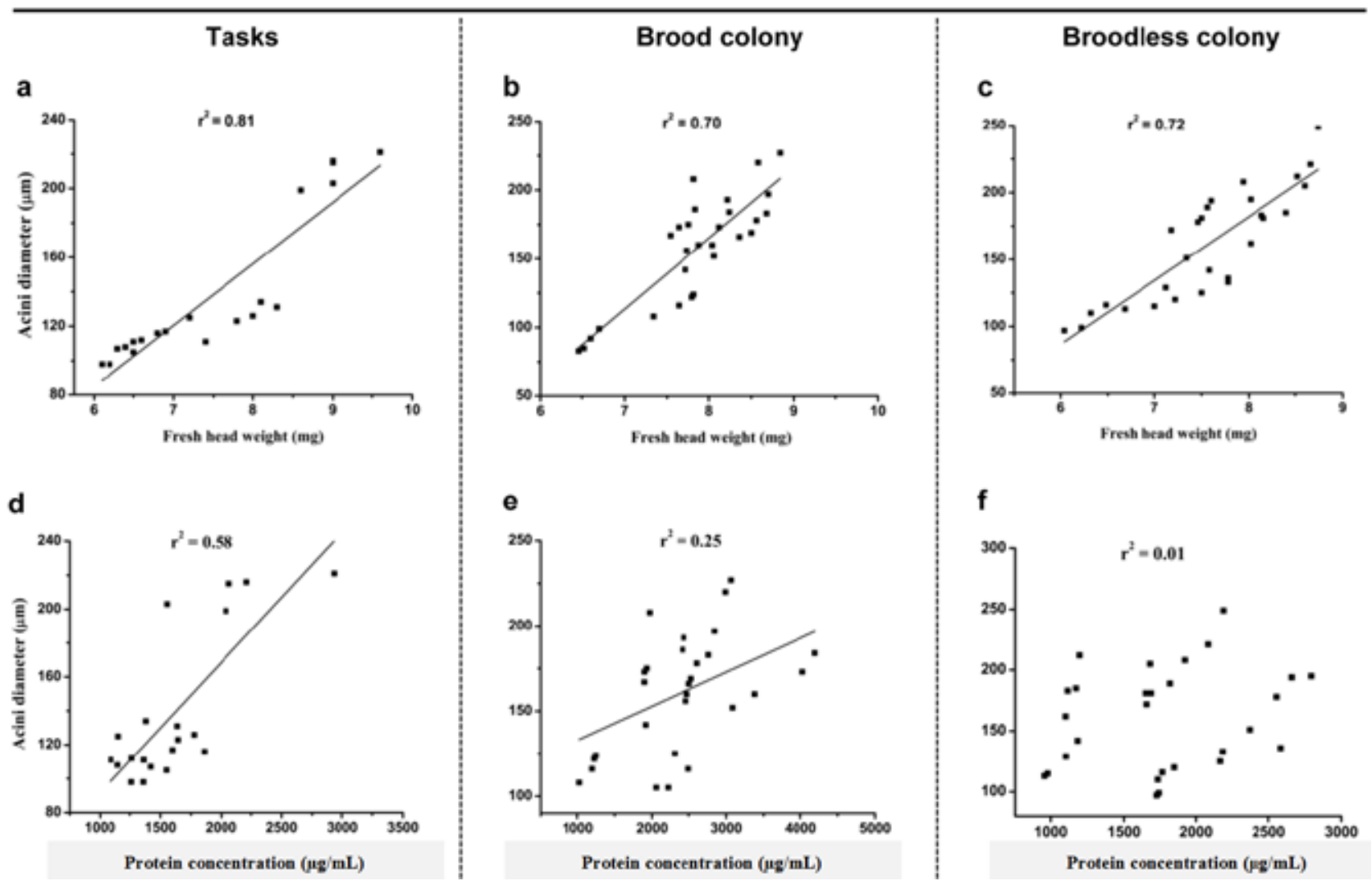

Fig. 5. Correlations among morphometric parameters in bees. Hypopharyngeal gland acini diameters in worker bees were correlated to fresh head weights in bees in the (a) task groups, (b) brood colony, and (c) broodless colony. Relationships between hypopharyngeal gland acini diameters and protein concentrations in workers bees in the (d) task groups, (e) brood colony and (f) broodless colony.
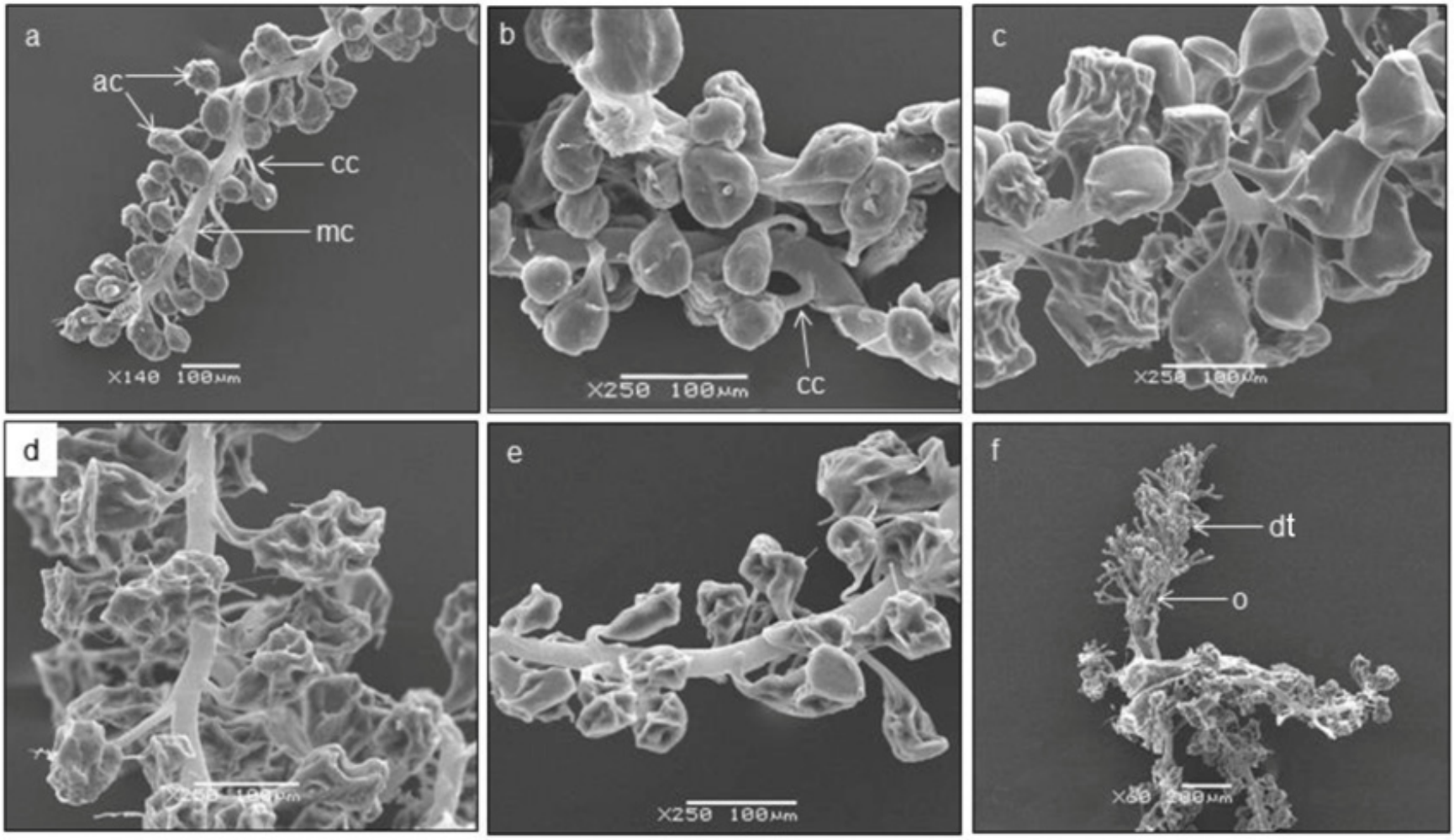

Fig. 6. Scanning electron microscopy micrographs show hypopharyngeal gland (HPG) morphology of bees at different stages. (a) Overall structure of HPG from a worker bee; (b) a section of HPG from a newly emerged bee, when the HPG is not completely developed; (c) a section of HPG from a nurse bee, when the HPG is completely developed; (d) the HPG of a guard bee shows some degeneration; (e) the HPG from a forager bee is further shrunken; (f) HPG ducts that open onto the main channel. ac: acinus; cc: canaliculi; dt: duct; mc: main channel; o: opening. 
development (Fig. 6c). In the guard bees, the HPG showed regression (Fig. 6d). In forager workers, the gland had lost turgidity (Fig. 6e).

\section{Histochemistry of HPG}

Each bee task group has a well-defined secretory cycle. Histochemical examinations of acini revealed changes in carbohydrates and proteins during the four different phases of the worker caste (Fig. 7 and 8). PAS highlight vesicular membranes due to their high content of glycolipids or sialoglycopeptides. Figure 7a illustrates a portion of HPG. We found that, in newly emerged workers, each acinus contained 6 - 9 cells (indicated by nuclei). The cell nuclei were surrounded by a smaller number of small secretory vesicles that were weakly stained with PAS, within the cytoplasm (Fig. 7b). In nurse bees, the acini also contained 6 - 9 cells, but they were surrounded by numerous, well developed secretory vesicles that were deeply stained with PAS; this staining was evidence of higher synthesis activity in nurse cells than in newly emerged workers (Fig. 7c and 7d). The cell cytoplasms were well organized, with large, round nuclei. In this task group, the acini were spherical in shape. However, in the guard bees, the secretory vesicles were condensed, and the PAS stain was weak compared to the strongly stained vesicles in nurse bees (Fig. 7e). In forager bees, vesicles were much smaller than those observed in the other worker stages; however, the PAS staining intensity was similar to that observed in nurse bees (Fig. 7f).

Acini were stained with NHS to evaluate protein content and localization. The acini in all stages showed purple-pink NHS staining in the nuclei. Newly emerged bees were characterized by weak positive staining in the secretory vesicles and cytoplasm (Fig. 8a). In the nurse bees, the NHS did not react with secretory vesicles, but it reacted strongly with proteins in the cytoplasm and at the periphery of the acini cells; (Fig 8b). In the guard and forager bees, the cytoplasm and secretory vesicles were weakly stained (Fig. 8c and 8d).
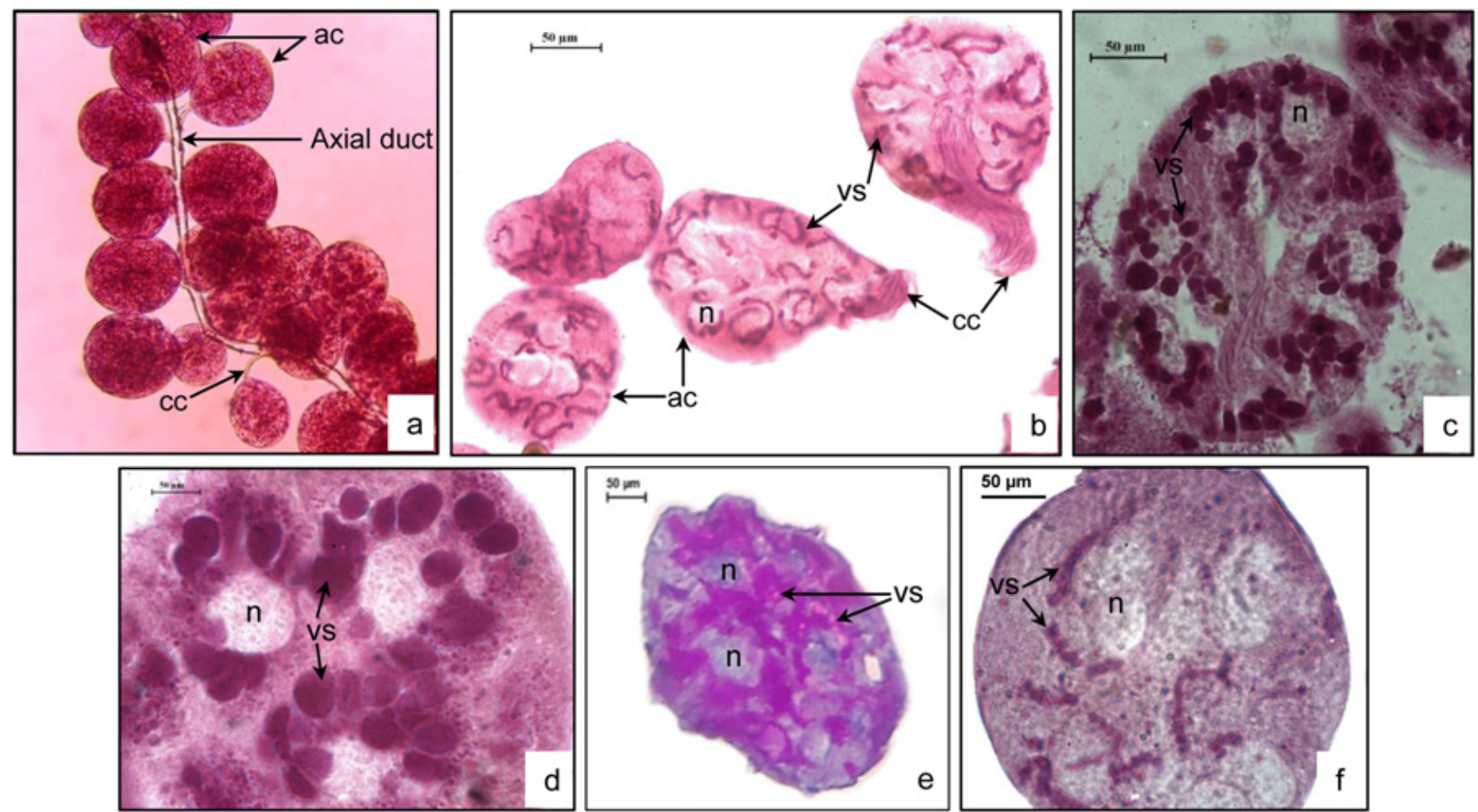

Fig. 7. Light micrographs of hypopharyngeal gland (HPG) acini illustrate the localization of carbohydrates with PAS staining. (a) Intact HPG stained with hematoxylin-eosin. The acini (ac) drain through individual canaliculi (cc), which are connected to the main axial duct. (b) Acini of newly emerged bees show weak PAS staining in the secretory vesicles (vs) (magnification, 40×). (c) In the acini of a nurse bee, the secretory vesicles are well-developed and stained a deep red-pink color; nuclei are colored light green (40×). (d) A section of an acinus in the HPG from a nurse bee highlights the secretory vesicles (vs) and nuclei (n) stained with PAS (100x). (e) A medial section of an acinus in the HPG of a guard bee shows degeneration of secretory vesicles, which are weakly stained with PAS (40x). Secretory vesicles are scattered within the cytoplasm, with no clear boundary. (f) Shrinkage of secretory vesicles in an acinus from a forager bee. Vesicles are stained a light red-pink (100×). ac: acinus; cc: canaliculi; n: nucleus; vs: vesicle. 

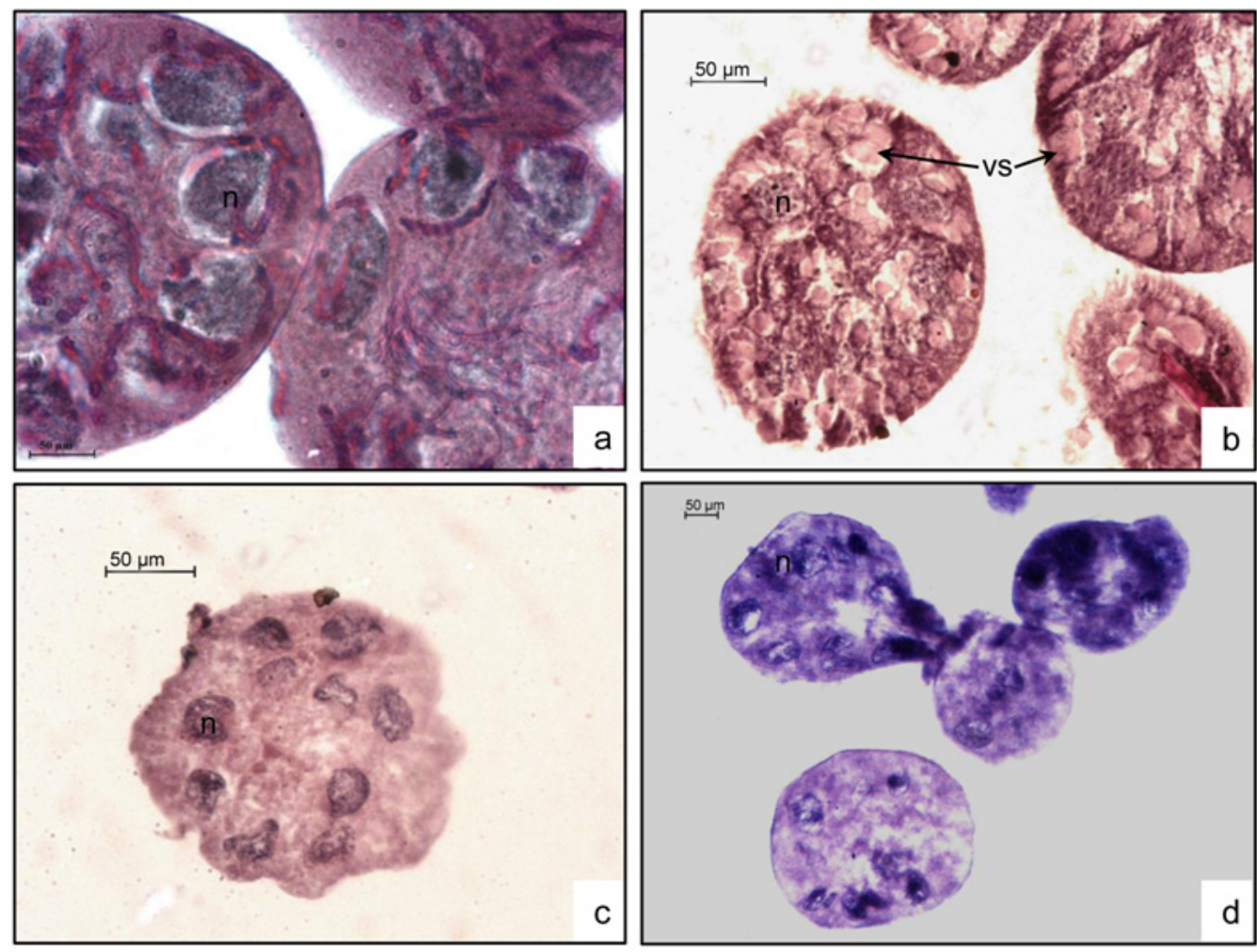

Fig. 8. Light micrographs of hypopharyngeal gland acini show protein content stained with NHS. (a) Acini from newly emerged bees show staining of the cytoplasm and nuclei in light purple-pink and deep purple-pink, respectively (100×). (b) The cytoplasm in the acini from a nurse bee is stained dark magenta, indicating a high concentration of protein (40x). (c) The cytoplasm and nuclei of an acinus from a guard bee are stained light- pink and purple-pink, respectively (100x). (d) The cytoplasm of acini from a forager bee contains weakly stained secretory vesicles, which indicates low protein content (20x). n: nucleus; vs: vesicle.

\section{DISCUSSION}

HPG activity may be an important indicator of the physiological mechanism that underlies the division of labor that arises with age progression in worker bees. With age-associated task switching, the structure and function of the HPG have also been shown to vary. Our morphological analysis of the HPGs in A. c. indica revealed that they are composed of secretory units that are individually connected to a single axial duct of the hypopharyngeal plate by means of excretory canaliculi. We found that the total length of the HPG in this species $(1.15 \mathrm{~cm})$ was slightly longer than that of $A$. mellifera $(1 \mathrm{~cm}$; CruzLandim and Costa, 1998). The workers of $A$. c. indica had the same HPG type (Type-4) and secretory units showed the same morphological pattern as those reported for $A$. mellifera.

The present study demonstrated that both the size and shape of HPG acini in worker bees of $A$. c. indica were associated with the shifts in the division of labor. The HPG displayed three different stages in adult workers; the first was underdeveloped, the second was a growth period, and the third was degeneration. The newly emerged bees, which spent most of their time walking and inspecting cells, had HPGs that were not completely developed. These HPGs were weakly stained with NHS, indicating that they held small amounts of protein. This finding was consistent with previous findings, which showed that small-sized glands were less functional than the larger glands (Huang et al., 1989).

At 3 - 4 days after emergence, the worker bees were engaged in nursing the young bees with the protein-rich substance released from their HPGs. With histochemistry, we found that the nurse bees had HPGs with numerous secretory vesicles that were strongly stained with PAS, which indicated that the acinar cells were well-developed. This finding suggested that, during this stage, protein synthesis was highly active. Similar findings were described in A. mellifera and A. cerana (Deseyn and Billen, 2005; Suwannapong et al., 2010). When workers switched to performing outside tasks, such as guarding, the HPG began to shrink, and accordingly, the production of protein also diminished. More HPG shrinkage 
was noticed in the foragers. This reduction in HPG size may result in reduced protein secretion, which may lead to a reduced ability to care for the brood. However, there were no differences in HPG protein concentrations between guard and the forager bees. In nurse bees, all portions of the acini cells, except the secretory vesicles, showed a strong positive reaction to NHS, indicating the presence of proteins. The NHS staining was stronger in HPGs of nurse bees than in HPGs of other task groups.

Both age and brood status in the hive were significantly related to the diameters of the HPG acini in the worker bees. HPG acini were in a developmental stage in newly emerged bees. By the $8^{\text {th }}$ day after emergence, the HPGs were well-developed and the acini had almost doubled in size compared to those in newly emerged bees, regardless of whether they were placed in brood or broodless colonies. This result was consistent with the findings of Hrassnigg and Crailsheim (1998) and Deseyn and Billen (2005), who investigated HPG development in A. mellifera. Although physiological activity changes when nurse bees turn to foraging, the rate of protein synthesis does not necessarily depend on the size of the gland. The present results demonstrated that 8-day and 16-day workers from both brood and broodless colonies had voluminous glands, but the protein concentrations were lower than those found in the 4-day and 12-day old workers. The difference in HPG protein concentrations between workers of brood and broodless colonies was an indication that the status of the brood also affected protein synthesis (Brouwers, 1982; Fluri et al., 1982; Moritz and Crailsheim, 1987; Deseyn and Billen, 2005).

The absence of a brood affected the nurse bees and the worker bees of other age groups. Worker bees that were 16, 18, and 21 days of age, including foragers, had HPGs with lower protein concentrations in the broodless colony than those of the brood colony. This low protein content was due to the reduced consumption of pollen, which declined due to the lack of a brood. Foragers reduce their pollen foraging when the brood is sparse or absent (Hrassnigg and Crailsheim, 1998). During the foraging period, the foraging bees produce carbohydrate-metabolizing enzymes for nectar processing. The present findings on HPG morphometrics differed from a previous study by Suwannapong et al. (2010), who reported that the acini volumes in $A$. mellifera and $A$. cerana were slightly higher in foragers than in guards. In that study, they also found extracellular spaces between the acinar cells in foragers. In the present study, we found that foragers had the smallest acini volumes, and we did not observe any extracellular space among adjacent acinar cells.

Interestingly, morphometric studies on the hymenopteran wasp, Polistes versicolor, have shown no relationship between age and HPG development. In contrast, members of the same age groups are capable of performing different activities (Britto et al., 2004). However, among those wasps, in the reverted foragers, the HPG could redevelop and resynthesize brood food in colonies that lacked nurse bees (Huang and Robinson, 1996).

Based on the present observations on the morphology, histochemistry, and protein content of the HPG in A. c. indica, we concluded that brood care behavior plays a role in stimulating protein secretion, and thus, the presence of a brood influences the development of the HPG.

\section{ACKNOWLEDGMENTS}

The first author gratefully acknowledges the financial assistance provided in the form of a SRF from UGC, New Delhi, under the Maulana Azad National Fellowship Scheme. Thanks also go to the Head, Department of Zoology, North-Eastern Hill University, Shillong, for providing research facilities.

\section{REFERENCES}

Bloom J. V. D. (1993) Individual differentiation in behaviour of honey bee workers (Apis mellifera L.). Insectes Sociaux 40: 345-361.

Bradford M. M. (1976) A rapid and sensitive method for the quantitation of microgram quantities of protein utilizing the principle of protein-dye binding. Analytical Biochemistry 72: 248-254.

Britto F. B., Caetano F. H., Moraes R. L. M. S. D. (2004) Comparative analysis of morphological, structural and morphometric Patterns of Polistes versicolor (Olivier) (Hymenoptera: Vespidae) hypopharyngeal glands. Neotropical Entomology 33(3): 321-326.

Brouwers E. V. M. (1982) Measurement of hypopharyngeal gland activity in the honey bee. Journal of Apicultural Research 21:193-198.

Brouwers E. V. M. (1983) Activation of the hypopharyngeal glands of honeybees in winter. Journal of Apicultural Research 22: 137-141. 


\section{J. APRC. SCLI. VOL. 58 NO. 2 2014}

Costa A. M. F., Cruz-Landim C. (1977) Estudocomparativo das glandulas do sistema salivar dos Apidae sociais (Hymenoptera). Revista Brasileira de Biologia 37(3): 649663.

Costa R. A. C. (2002) Glandulas Hipofaringeas. In: CruzLandim C., Abdalla F. C. (Eds.) Glandula sexocrinas das abelhas. Funpec. Brasil: 91-110.

Costa R. A. C., Cruz-Landim C. (1999) Occurrence and morphometry of the hypopharyngeal gland in Scaptotrigona postica Lat. (Hymenoptera, Apidae,Meliponinae). Journal of Bioscience 24: 97-102.

Costa R. A. C., Cruz-Landim C. (2000) Comparative study of hypopharyngeal gland in queens, workers and males of Scaptotrigona postica Latreille (Hymenoptera,Apidae, Meliponini). Biocell 24: 39-48.

Crailsheim K. (1991) Interadult feeding of jelly in honeybee (Apis mellifera L.) colonies. Journal of Comparative Physiology 161B: 55-66.

Crailsheim K., Stolberg E. (1989) Influence of diet, age and colony condition upon intestinal proteloytic activity and size of the hypopharyngeal glands in the honey bee (Apis mellifera L.). Journal of Insect Physiology 35: 595 602.

Cruz-Landim C. (1967) Estudo comparativo de algumas glndulas das abelhas (Hym., Apoidea) erespectiva simplicates evolutivas. Arquivos de Zoologia 15(3): 177-290.

Cruz-Landim C., Costa R. A. C. (1998) Structure and function of the hypopharyngeal glands of hymenoptera:a comparative approach. Journal of Comparative Biology $3(2): 151-163$.

Cruz-Landim C., Hadek R. (1969) Ultrastructure of Apis mellifera hypopharyngeal gland. In: Proceedings of the $\mathrm{VI}$ Congress. Bern- Switzerland. 15-20 September 1969: 121-130.

Cruz-Landim C., Saenz M. H. P. (1972) Estudo comparativo de algumas glndulas dos Vespoidea (Hymenoptera). Papéis Avulsos do Departamento de Zoologia 25(24): 251-263.

Cruz-Landim C., Costa R. A. C., Silva-De-Moraes R. L. M. (2000) Hypopharyngeal gland function, glandular senescence and gland reactivation. In: Austin A. D. (Ed.) Hy- menoptera: Evolution, Biodiversity and Biological Control. CSIRO. Australia: 54-59.

Cruz-Landim C., Silva-De-Moraes R. L. M., Costaleonardo A. M. (1987) Ultra-estrutura das glndulashipo far İngeasde Melipona quadrifasciata anthidioides Lep. (Hymenoptera, Apidae). Naturalia 11: 89-96.

Deseyn J., Billen J. (2005) Age-dependent morphology and ultrastructure of the hypopharyngeal gland of Apis mellifera workers (Hymenoptera, Apidae). Apidologie 36: 49-57.

Dey S. (1993) A new rapid air-drying technique for scanning electron microscopy using tetramethylsilane: application to mammalian tissue. Cytobios 73: 17-23.

Fluri P., Lscher M., Wille H., Gerig L. (1982) Changes in weight of the pharyngeal gland and the haemolymph titres of juvenile hormone, protein and vitellogenin in worker honey bees. Journal of Insect Physiology 28: $61-68$.

Gama V., Cruz-Landim C. (1982) Estudo comparative das glndulas do sistema salivar de formigas (Hymenoptera, Formicidae). Naturalia 7: 145-165.

Hrassnigg N., Crailsheim K. (1998) Adaptation of hypopharyngeal gland development to the brood status of honeybee (Apis mellifera L.) colonies. Journal of Insect Physiology 44: 929-939.

Huang Z. Y., Robinson G. (1996) Regulation of honey bee division of labor by colony age demography. Behavioral Ecology Sociobiology 39: 147-158.

Huang Z. Y., Otis G. W., Teal P. E. A. (1 989) Nature of brood signal activating the protein synthesis of hypopharyngeal gland in honeybees Apis mellifera (Apidae: Hymenoptera). Apidologie 20: 455-464.

Humason G. L. (1962) Animal tissue techniques. W. H. Freeman and Co. San Francisco. 468 pp.

Klaudiny J., Hanes J., Kulifajova J., Albert S. (1994) Molecular cloning of two cDNAs from the head of the nurse honey bee (Apis mellifera L.) for coding related proteins of royal jelly. Journal of Apicultural Research 33: 105 111. 
Knecht D., Kaatz H. H. (1990) Patterns of larval food production by hypopharyngeal glands in adult worker honey bees. Apidologie 21:457-467.

Kratky E. (1931) Morphologie und Physiologie der DrseninKpf und Thorax der Honigbiene (Apis mellifera L.). Zeitschriftfür wissenschaft liche Zoologie 139: 120200.

Kubo T., Sasaki M., Nakamura J., Sasagawa H., Ohashi K., Takeuchi H., Natori S. (1996) Change in the expression of hypopharyngeal gland proteins of the worker honeybees (Apis mellifera L.) with age and/or role. Journal of Biochemistry 119: 291-295.

Lauer S. M. S. (1975) Estrutura macro e microscUpica das glndulas do sistemasalivarnascastas de Bombusatratus Franklin, 1913 (Hymenoptera-Apidae). Disserta o de Mestrado. Universidade Federal doParan. Curitiba. 74 pp.

Michener C. D. (1974) True honey bees. In: Michener C. D. (Ed.) The social behavior of the bees. Harvard University Press. Cambridge. Massachussetts: 347-349.

Mohammedi A., Crauser D., Paris A., Conte Y. L. (1996) Effect of a brood pheromone on honeybee hypopharyngeal glands. Neuroscience 319: 769-772.

Moritz B., Crailsheim K. (1987) Physiology of protein digestion in the midgut of the honeybee (Apis mellifera L.). Journal of Insect Physiology 33: 923-931.
Ohashi K., Natori S., Kubo T. (1 999) Expression of amylase and glucose oxidase in the hypopharyngeal gland with an age-dependent role change of the worker honeybee (Apis mellifera L.). European Journal of Biochemistry 265: 127-133.

Origin Pro 8 (Origin Lab, Northampton, MA).

Patel N. G., Haydak M. H., Gochnauer T. A. (1960) Electrophoretic components of the proteins in honeybee larval food. Nature 186: 633-634.

Ribbands R. (1953) The behaviour and social life of the honeybees. Bee Research Association. London. 352 pp.

Silva R. L. M. D. M., Caramello K. A., Feddersen A. Jr. (1985) Estudoscitofotom Etricosdasg Indulashipo faringeas de operrias de Scaptotrigona posticae Melipona quadrifasciata anthidioides Lep. (Hymenoptera, Apidae). Naturalia 10: 147-155

Snodgrass R. E. (1956) Anatomy of the honeybee. New York. Comstock Publisher Association. Ithaca. 334 pp.

Suwannapong G., Chaiwongwattanakul S., Benbow M. E. (2010) Histochemical comparison of the hypopharyngeal gland in Apis cerana Fabricius, 1793 workers and Apis mellifera Linnaeus, 1758 workers. Psyche 2010(2010): 1-7. DOl: 10.1155/2010/181025 